\title{
Analysis of the effect of LPG on the Performance and Frictional Power Loss for SI Engine
}

\author{
Pundlik N. Patil, Dheeraj S. Dehmukh, Vilas S. Patil
}

\begin{abstract}
Due to the depletion of conventional fossil fuels and the energy crises with emission problems today, research and development have been concentrated on reducing fuel consumption by using different alternative fuel and reducing a toxic component in combustion products. Liquefied petroleum gas is a suitable fuel for internal combustion engine since the octane number is also high nearly 109 and therefore cars, medium and heavy duty vehicles have been using propane or propane/butane mixture successfully. The engine parameter like engine speed, load, viscosity of oil, cylinder size, brake power, frictional power, indicated power, are considered for comparative analysis for bi-fuel engine fueled by petrol and liquefied petroleum gas for the performance of the test engine and frictional losses. The experiment was carried out with morse procedure to compare the frictional power losses which are always more for liquefied petroleum gas than the petrol.
\end{abstract}

Keyword-Frictional power loss, liquefied petroleum gas, morse test, mechanical efficiency, fuel consumption

\section{INTRODUCTION}

Gasoline or petrol is a conventional fuel which is made available from extraction through the refineries majorly from gulf countries and India is mainly procure these oils from them. Due to the depletion of fossil fuels the research work is become stagnant towards alternative fuels. Alternative fuels like liquefied petroleum gas (LPG) are getting more and more importance due to rising fuel cost, and environmental pollution and emission to overcome these problems. Also the use of LPG asan alternative fuel to petrol is commonly used in spark ignition engine in large quantities due less cost for the users, emissions are also at lower side, transportation and storage are easier than other gaseous fuels, higher calorific value and octane number. But at the same time use of LPG fuel are having some disadvantages such as the volumetric efficiency and brake power are reduced[5],[11].

Revised Manuscript Received on July 25, 2019.

Pundlik N. Patil, Ph.D. Research Scholar, SGDCOE, Jalgaon (India) e-mail - pnpatil09@rediffmail.com

Dheeraj S. Dehmukh, Prof.\& Head, GHRCOE, Nagpur (India). e-mail-deshmikh.dheeraj @gmail.com

Vilas S. Patil, Prof UICT, KBCNMU, Jalgaon (India)

e-mail-.vilaspatil24@yahoo.com

\section{OBJECTIVE}

The purpose of this experimental investigation is to study the effect of liquefied petroleum gas using as a engine fuel with petrol on performance of multi cylinder engine internal combustion engine running on Liquefied Petroleum Gas are well proven technologies and work much like gasolinepowered spark ignition engine[14]

Pure petrol was used as a reference fuel The main objectives of this work are:

(i) To compare important properties ofliquefied petroleum gas(LPG) withpetrol.

(ii) To compare the Performance of the engine for both fuels.

(iii) To compare the Frictional power losses withthose of purepetrol.

Table 1: Properties of LPG \& other fuel.

\begin{tabular}{|c|c|c|c|c|}
\hline Properties & $\begin{array}{c}\text { LPG } \\
\left(\mathrm{C}_{3} \mathrm{H8}\right)\end{array}$ & $\begin{array}{c}\text { Petrol } \\
\left(\mathbf{C H}_{8} \mathbf{H}_{18}\right)\end{array}$ & $\begin{array}{c}\text { Ethanol } \\
\left(\mathrm{C}_{2} \mathrm{H}_{5} \mathrm{O}_{\mathrm{H}}\right)\end{array}$ & $\begin{array}{c}\text { Methanol } \\
\left(\mathrm{CH}_{3} \mathrm{O}_{\mathrm{H}}\right)\end{array}$ \\
\hline Molecular wt. (kg/ kmol) & 44.10 & 114.0 & 46.01 & 32.0 \\
\hline Density $\left(\mathrm{kg} / \mathrm{cm}^{3}\right)$ & 0.530 & 0.765 & 0.785 & 0.793 \\
\hline Air-fuel ratio & 15.7 & 14.6 & 9.0 & 6.5 \\
\hline Calorific value $(\mathrm{MJ} / \mathrm{kg})$ & 46.3 & 44.0 & 26.9 & 22.7 \\
\hline Heat of vaporization $(\mathrm{MJ} / \mathrm{kg})$ & 0.426 & 0.36 & 0.92 & 1.2 \\
\hline Research Octane No. & 109 & $91-99$ & 129 & 136 \\
\hline
\end{tabular}

It can be seen from the Table 1, Petrol and alcohols have lower calorific value than LPG as a fuel [12]

\section{ENGINE TEST PROCEDURE}

A Spark ignition Engine is modified into bi-fuel mode for petrol and LPG fuel by introducing LPG kit for bi-fuel conversion mode. The Converted engine will have flexibility of operating either on conventional petrol or LPG. The test rig consist of a four cylinder, four stroke spark ignition engine coupled to hydraulic dynamometer, naturally aspirated, 118NE Premier,1.2 litre capacity with maximum output $39 \mathrm{KW}$. The engine is mounted on a rigid bed and is coupled toa loading device as a hydraulic dynamometerthrough a flexible coupling

In this, cooling water pipe line is connected to a water supply line. Fuel consumption is measured by acalibrated burette for $50 \mathrm{ml}$ quantity of petrol while LPG fuel consumption is measured by electronic weight balance.

The consumed air is measured with the help of mild steel tank which is

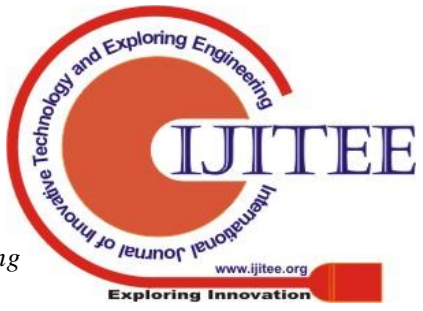


fitted to a standard orifice and $\mathrm{U}$ - tube manometer which measure the pressure inside the tank for the height of the air column. To conduct morse test, an arrangement is provided to cut off the ignition to each spark plug and to record temperature of exhaust gases multichannel digital temperature indicator is used and cooling water inlet and outlet .temperature are measured bythe thermocouple which are fitted on well-provided in the pipelines. The exhaust gas pipe is connected to a shell tube type heat exchanger wherein the gases are cooled by a cooling water line. Separate thermo couple are provided to measure the exhaust gas outlet temperature from calorimeter and calorimeter cooling water inlet and outlet temperature. A charged battery is used to start the engine and the rotameter is used for the measurement of water flow to the engine. The experimentation is carried out to find the power developed in each cylinder for the engine and it basically gives the relationship between Indicated power and brake power. It is assumed that friction and pumping losses do not change and remain same when the cylinder is in firing condition as well as in inoperative condition. Using this test the frictional losses in the IC engine can be easily calculated. The main intention of carrying out this Morse test in internal combustion engine is to provide an easy method of calculating the frictional losses. The total brake power of the engine is first calculated using a dynamometer and the process is repeated with one cylinder off at each step and the difference between total brake power and brake power of remaining cylinder gives the indicated power of first cylinder and so on. Once friction power is obtained the mechanical efficiency of the engine can be calculated.[1],[2],[7],[8],[9]

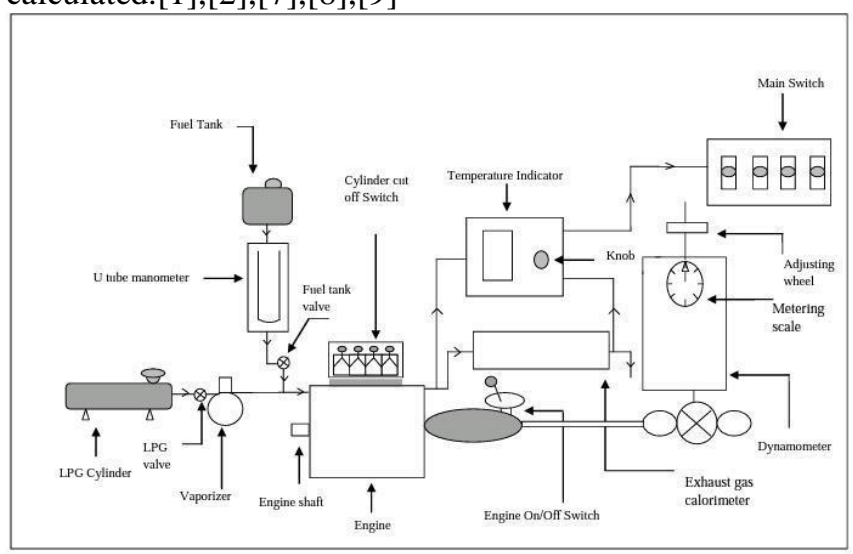

Figure (a) : Experimental Test Set up

Morse tests were carried out on the above engine using petrol and liquefied petroleum gas (LPG). First the engine was run with petrol and different parameters were recorded. The tests were performed at a various speed of the experiments were repeated using LPG \& petrol. The following quantities were recorded during the experiments:
Engine Speed
Load on the engine
fuel consumption
$=\mathrm{Nrpm}$
$=\mathrm{W} \mathrm{Kg}$
$=\mathrm{Q} \mathrm{Kg} / \mathrm{hr}$
exhaust gastemperature
$=$ Toc

\section{RESULT \&DISCUSSIONS}

Following are the graphs which has obtained for various engine performance parameters from the above experimental investigation of LPG fuel compared with petrol

- The graph no. 1 shows that the frictional power are always increases as the speed increases for boththe LPG and petrol fuel and it is more for LPGfuel.

- The fuel consumption are less for lower speed but as as speed increases fuel consumption also increases in graphno. 2 - Specific fuel consumption are decreases as load on engine increases as shown in above graph3.

- From the graph no. $4 \& 5$, the brake thermal efficiency and indicated thermal efficiency bothare more for low load but at higher load both efficiencies become less for LPGfuel.

The effect of LPG are having an adverse effect on S.I.engine performance as shown in graph $6 \& 7$, The Mechanical efficiency and volumetric efficiency both are decreases by $8-10 \%$ and $6-8 \%$ respectively as the load increases

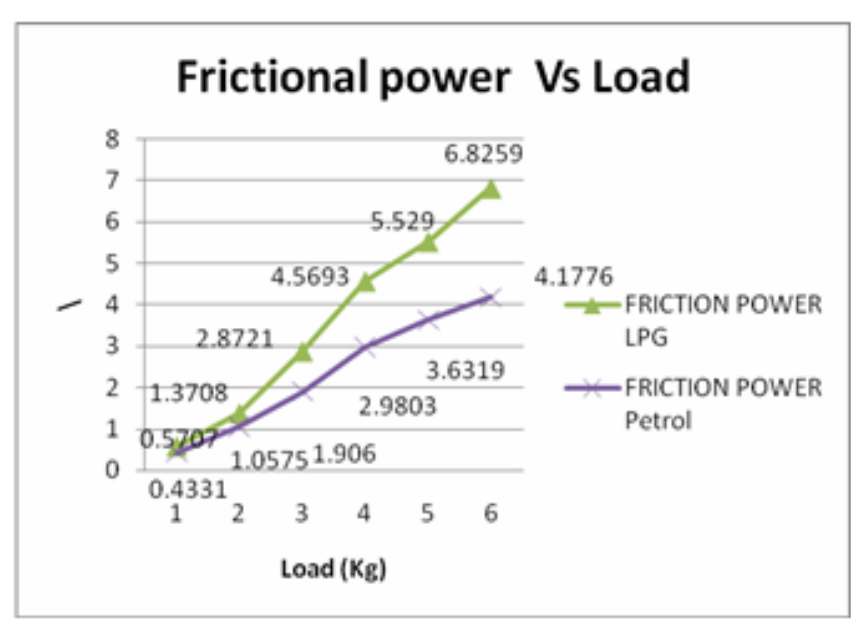

Graph 1 : Frictional Power Vs Load

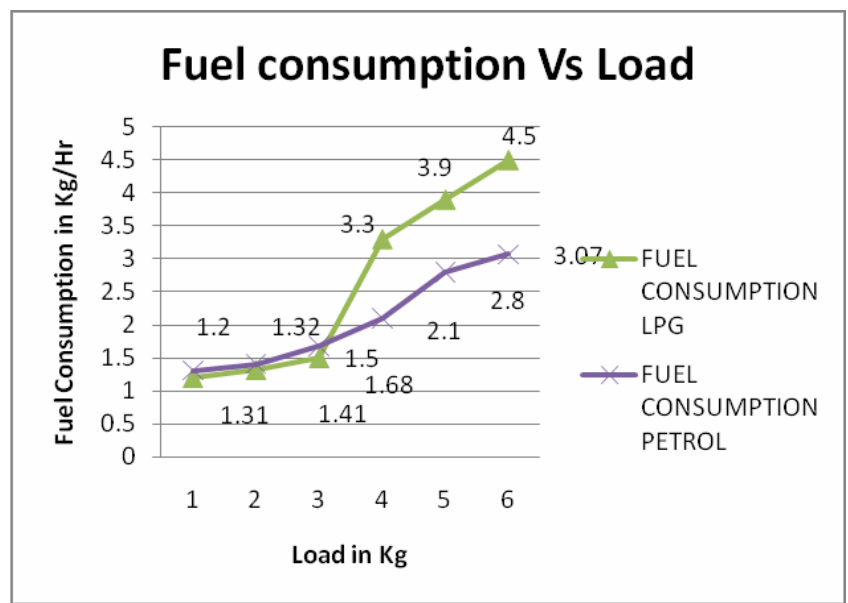

Graph No. 2 Fuel Consumption VsLoad 


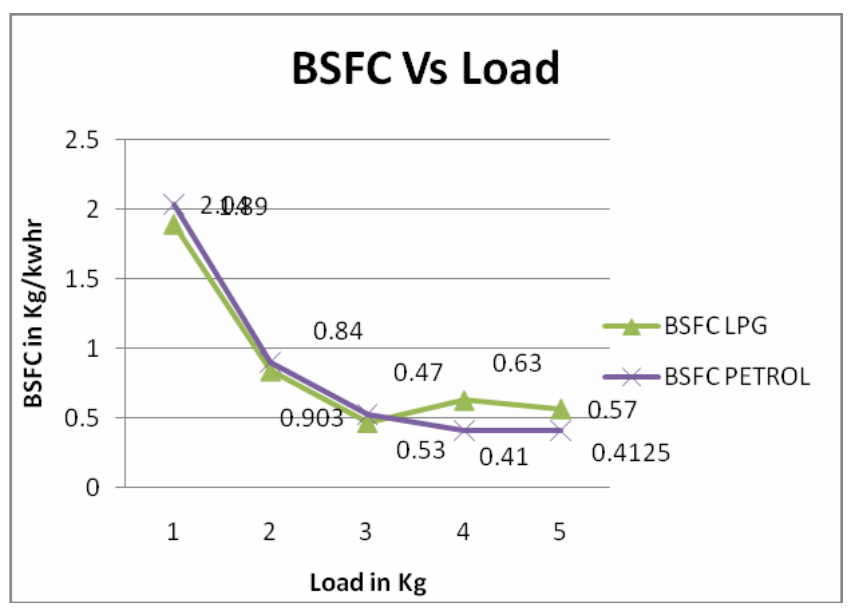

Graph No. : 3 BSFC VsLoad]

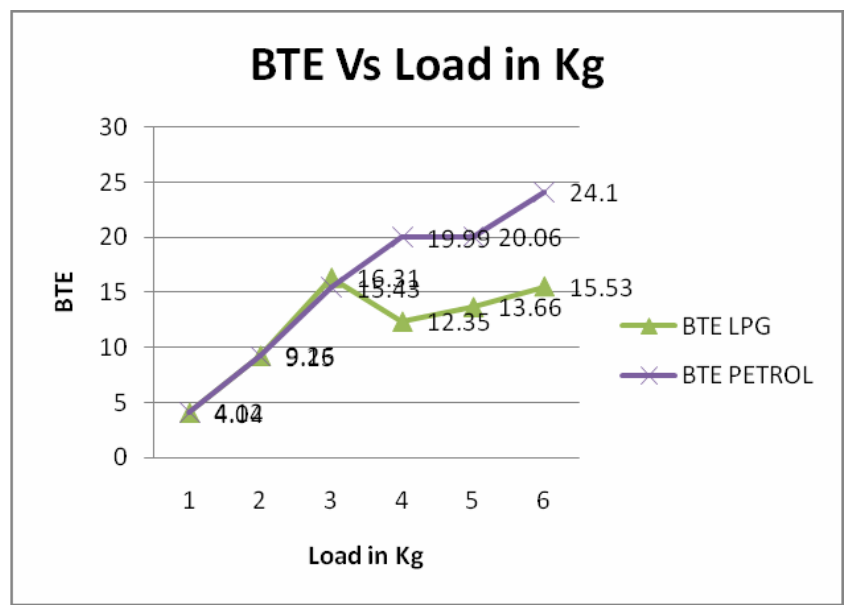

Graph No. : 4 BTE Vs Load in Kg

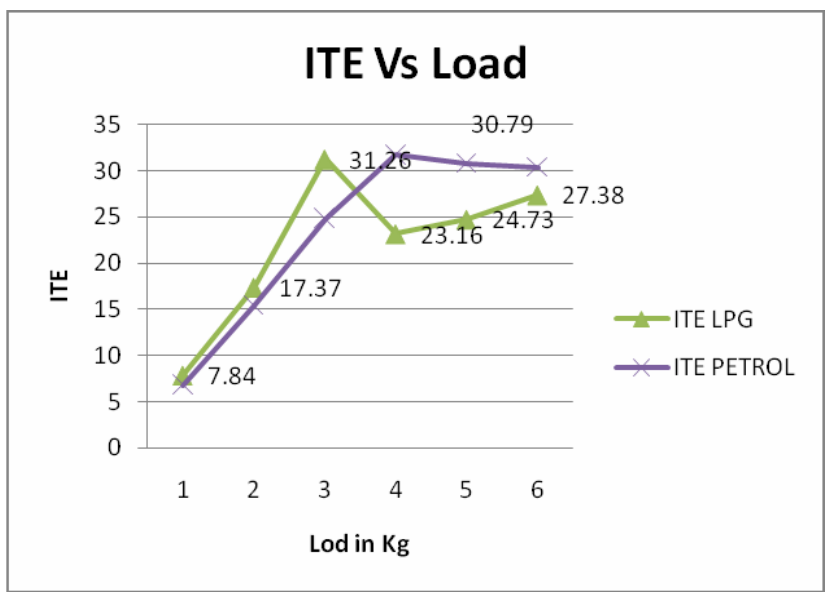

Graph No. :5 ITE Vs Load

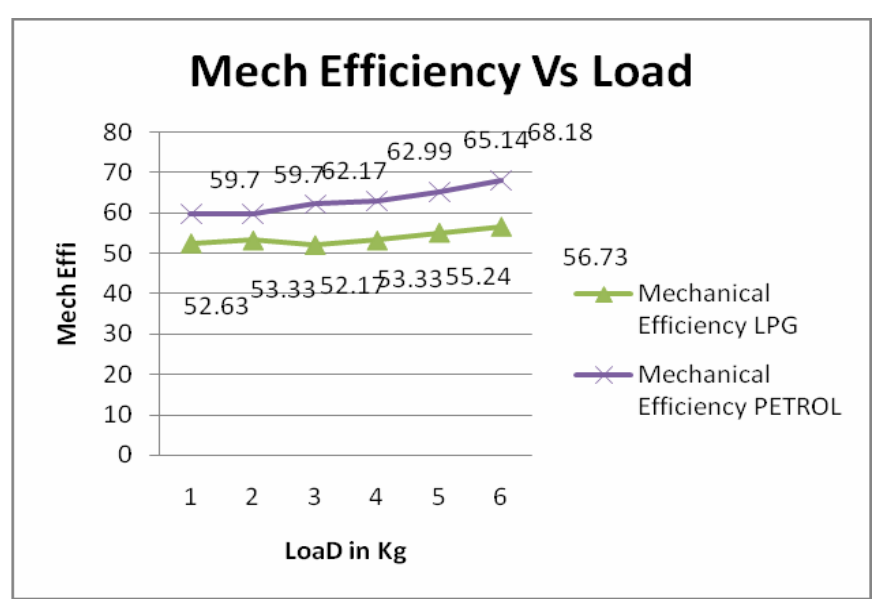

Graph No. :6Mech EfficiencyVsLoad

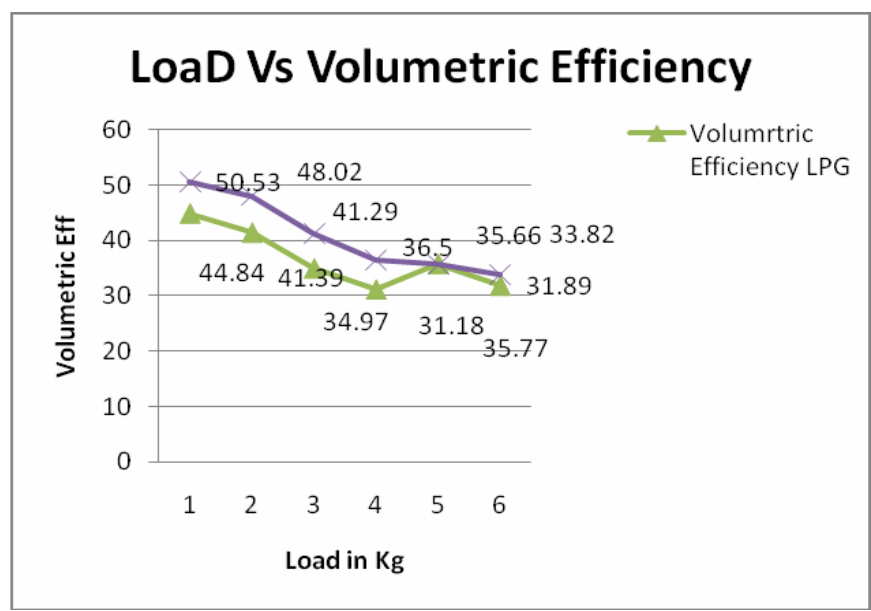

Graph No. : 7 Load Vs Volumetric Efficiency

\section{CONCLUSION}

In the present work, experimental setup for morse test has done with proper modification to evaluate various performance parameters of given test engine with petrol and LPG as a fuel. The effect of LPG as a fuel on engine performance parameter and characteristics such as friction power, indicated power, brake power, basic specific fuel consumption, and volumetric efficiency are carried out and from the investigation it is observed that, the friction power losses are increases for LPG fuel at higher load while brake power reduced by $10-15 \%$.

The volumetric efficiency for LPG fuel is always less than petrol fuel; frictional losses are also more for LPG fuel. Fuel consumption is at higher side in case of LPG than petrol as well as thermal efficiencies is also high with petrol.Among all the above, LPG fuel is having asbetter antiknock characteristics, high octane rating and cost effective and less emission pollutant.

\section{FUTURE SCOPE}

More research work may be performed on useof LPG in internal 
combustion engine to improve the performance ofof the engine by introduction of new technology.

\section{ACKNOWLEDGMENT}

Authors are thankful to the Shram Sadhana Bombay Trusts, College of Engineering and Technology, Bambhori, Jalgaon. (M.S.) for providing library and laboratory facility. The authors also thankful to the staff and colleagues for their useful discussions

\section{REFERENCES}

[1] John. B. Heywood, "Internal Combustion Engine Fundamentals", Tata McGraw Hill, ISBN - 13:978 - 1 -25-900207-6,PP 725741, 2011

[2] V. Ganeshan, "Internal combustion engine" Tata McGraw Hill, 2006.

[3] C. S. Mistry, "Comparative assessment on performance of multi cylinder engine using CNG,LPG and Petrol as a fuel" SAE Technical Paper , 2005-01-1056,2005

[4] Hakan Bayraktar, Orhan Durgun " Investigating the effect of LPG on spark ignition engine combustion and performance, " Energy Conversion and management Vol. 46, PP. 2317-2333, 2005

[5] Ali M. Pourkhesalian, Amir H. Shamekhi, Farhad Salimi, "Performance and emission comparison and investigation of alternative fuels in SI engines," SAE International, ISSN: 0148-719.1, 2009.

[6] R. R. Saraf, S. S. Thipse , P. K. Saxsena, "Comparative emission analysis of Gasolene/ LPG automotive bi-fuel engine.", Word academy of Science, Engineering and Technology, Vol. 3, 2009.

[7] Pundlik Nivrutti Patil, Dheeraj Sheshrao Deshmukh, "Effect of Liquefied Petroleum Gas as a Fuel on Spark Ignition Engine Performance: A Critical Review" PRATIBHA: INTERNATIONAL JOURNAL OF SCIENCE, SPIRITUALITY, BUSINESS AND TECHNOLOGY (IJSSBT), Vol. 4, No. 1. Nov. 2015 ISSN 2277-7261 PP. 50-55

[8] Pundli k Nivrutti Patil, DheerajSheshrao Deshmukh, Jitendra Gulabrao Patil, "A Review on Liquid Petroleum Gas as a Fuel in Spark Ignition Engine Application" International Conference on Global Trends in Engineering, Technology and Management (IJETT), 2016, ISSN: 2231-5381 pp 124-128.2016

[9] Dhiraj S.Deshmukh, Pundlik N. Patil, Vilas, S. Patil, "Design of Experimental plan for effect of liquefied petroleum gas analysis on friction power loss in spark ignition engine.", International Conference on Global Trends in Engineering, Technology and Management (ICGTETM), 2017, ISSN: 2320-2882 pp 199-205.,2017

[10] Massimo Massi, "Experimental analysis on a spark ignition petrol engine fuelled with LPG(liquefied petroleum gas)", Energy 41Elsevier Limited, pp 252-260. 2012

[11] Venkata Ramesh Mamilla, V. Gopinath, C. V. Subbarao, "PerformanceandEmissioncharacteristicsof4strokepetrolengine fueled with Biogas/L.P.G. BLENDS", IJAET/ /Vol. II/Issue -I PP 209-213. March 2011

[12] Faraz A Khan, Sameer Usmani,Omar A Siddiqui, Salman M Khan, "Performance evaluation of ambassador car Spark Ignition engine Using aniline-petrol blends", IJERT, Vol. I issue 8,ISSN 2278-0181,pp1-9 October 2012

[13] M. Gumus, "Effects of volumetric efficiency on the performance and emissions characteristics of a dual fueled -gasoline and LPG spark ignition engine," Fuel Processing Technology,Vol. 92, PP. 1862-1867, May 2011.

[14] Sanjay D Bisen,. Yogesh R. Suple , "Performance evaluation of four stroke SI engine by direct injection of LPG," Vol. 1,ISSN: 2321-8134,10 october 2013 